\title{
Stimulation of catecholamine biosynthesis via the PKC pathway by prolactin-releasing peptide in PC12 rat pheochromocytoma cells
}

\author{
T Nanmoku, K Takekoshi, T Fukuda, K Ishii, K Isobe \\ and Y Kawakami
}

Department of Clinical Pathology, Institute of Clinical Medicine, University of Tsukuba, Tsukuba, Ibaraki 305-8575, Japan

(Requests for offprints should be addressed to K Takekoshi, Department of Clinical Pathology, Institute of Clinical Medicine, University of Tsukuba, 1-1-1 Tennoudai, Tsukuba, Ibaraki 305-8575, Japan; Email: K-takemd@md.tsukuba.ac.jp)

\begin{abstract}
We have previously shown that prolactin-releasing peptide (PrRP) stimulates catecholamine release from PC12 cells (rat pheochromocytoma cell line). However, it is not known whether PrRP also affects catecholamine biosynthesis. Thus, we examined the effect of PrRP on catecholamine biosynthesis in PC12 cells. PrRP31 $(>10 \mathrm{nM})$ and PrRP20 (>100 nM) significantly increased the activity and expression level of tyrosine hydroxylase $(\mathrm{TH})$, a rate-limiting enzyme, in catecholamine biosynthesis. However, the PrRP20-stimulated TH activity was markedly weaker than that of PrRP31. PrRP31 (>1 nM) and PrRP20 (>10 nM) significantly induced an increase in the level of PKC activity. Both Ro 32-0432 (a protein kinase $\mathrm{C}$ inhibitor) and $\mathrm{H} 89$ (a protein kinase $\mathrm{A}$ inhibitor)
\end{abstract}

effectively suppressed the PrRP31 (100 nM )-induced TH mRNA level. Next, we examined the effect of PrRP on mitogen-activated protein kinases (MAPKs). PrRP31 $(1 \mu \mathrm{M})$ significantly induced an increase in the activity of extracellular signal-related kinases (ERKs) and the stressactivated protein kinase/c-jun $\mathrm{N}$ terminal kinase (SAPK/ JNK). In contrast to ERKs and JNK, PrRP31 did not affect P38 MAPK activity. Consistent with these findings, pretreatment of cells with the MEK-1-inhibitor, PD$98059(50 \mu \mathrm{M})$, significantly inhibited the PrRP31 $(100 \mathrm{nM})$-induced increase in TH mRNA. These results indicate that $\operatorname{PrRP}$ stimulates catecholamine synthesis through both the PKC and PKA pathways in PC12 cells. Journal of Endocrinology (2005) 186, 233-239

\section{Introduction}

Prolactin-releasing peptide (PrRP) is a novel hypothalamic hormone, initially identified by Hinuma et al. (1998) by the method of 'reverse' pharmacology. A 31-amino-acid peptide (PrRP31), with no significant homology to any known hormone, was isolated that had prolactin-releasing properties. Post-translational modification of the same gene product can give rise to another form of PrRP, named PrRP20 (Hinuma et al. 1998).

More recently, PrRP and its receptors have been reported to be expressed in numerous areas of the central nervous system (CNS), such as the hypothalamus and brainstem. Interestingly, PrRP has been colocalized with tyrosine hydroxylase $(\mathrm{TH})$-expressing medullary $\mathrm{A} 1$ and A2 neurons, suggesting that the peptide may have functions other than acting as a prolactin-releasing factor, such as modulating catecholaminergic reactions (Marchese et al. 1995, Welch et al. 1995, Iijima et al. 1999, Fujii et al. 1999, Kimura et al. 2000, Langmead et al. 2000).

PrRP and its receptor are highly expressed in the adrenal medulla as well as human pheochromocytomas, suggesting that these peptides may affect the function of chromaffin cells in an autocrine and/or paracrine fashion (Roland et al. 1999, Chen et al. 1999, Nieminen et al. 2000, Takahashi et al. 2002). Very recently, PrRPimmunopositive cells have been colocalized with THexpressing cells in rat adrenal gland, confirming that PrRP may be produced in the adrenal medulla (Fujiwara et al. 2005). Combining these findings suggests that PrRP may play an important role in modulating catecholamine secretion and/or synthesis in a paracrine manner. Indeed, we have shown that PrRP may stimulate catecholamine secretion via the PKA pathway, but not the mitogenic effects in chromaffin cells (Nanmoku et al. 2003). However, it is not known whether PrRPs influence the biosynthesis of catecholamine in chromaffin cells.

The signal transduction pathways for the PrRP receptor (GPR10) remain to be determined. Kimura et al. (2000) showed that PrRP stimulates the extracellular signalrelated kinases (ERKs) in rat pituitary GH3 cells via Gi/Go, and they claimed that this is independent of intracellular $\mathrm{Ca}^{2+}$. In addition, activation of the stressactivated protein kinase/c-jun $\mathrm{N}$ terminal kinase (SAPK/ JNK) by PrRP is dependent on protein kinase C (PKC). Recently, Langmead et al. (2000) also demonstrated that 
PrRP stimulates the mobilization of intracellular $\mathrm{Ca}^{2+}$ from the endoplasmic reticulum in HEK-293-GPR10 cells, supporting the suggestion that the PrRP receptor (GPR10) could be coupled with the Gq-PLC pathway. These results indicate that PrRP may stimulate PKC activity.

In adrenal medullary cells, $\mathrm{TH}$ is a rate-limiting enzyme in the biosynthesis of catecholamines. TH activity can be regulated by both short- and long-term mechanisms. Short-term regulation of enzyme activity occurs at the post-translational level. Central to this regulation is the phosphorylation of $\mathrm{TH}$, which results in activation of the enzyme. Indeed, $\mathrm{TH}$ is phosphorylated and activated by a variety of protein kinases, including protein kinase $\mathrm{C}$ (PKC). Long-term regulation is exerted at the TH protein synthesis level after TH gene transcription (Holz et al. 1982, Dunn \& Holz 1983, Stoehr et al. 1986, Plevin \& Boarder 1988).

In the present study, we investigated the effect of PrRP31 and PrRP20 on catecholamine biosynthesis in the rat pheochromocytoma cell line PC12.

\section{Materials and Methods}

\section{Reagents}

Unless otherwise noted, all reagents were purchased from Wako Seiyaku (Tokyo, Japan). Rat PrRP31 and PrRP20 were obtained from the Peptide Institute (Osaka, Japan) and Phoenix Pharmaceuticals (Mountain View, CA, USA) respectively. The protein kinase C inhibitor, Ro 32-0432 was purchased from Calbiochem (San Diego, CA, USA).

Cells were preincubated for either $30 \mathrm{~min}$ with H89 $(10 \mu \mathrm{M})$ or Ro-32-0432 $(100 \mathrm{nM})$, or $60 \mathrm{~min}$ with PD98059 $(50 \mu \mathrm{M})$ and then exposed to rat PrRP31 $(100 \mathrm{nM})$. The experimental conditions for treatment of the cells with H89, Ro-32-0432 or PD98059 were identical to those described previously (Chabot-Fletcher \& Breton 1998, Alessi et al. 1995, Marley et al. 1995, Hwang et al. 1997).

\section{Cell culture}

The PC12 cell line (RCB009) was obtained from the RIKEN Cell Bank (Ibaraki, Japan). Cells were grown in $75 \mathrm{~cm}^{2}$ flasks in Dulbecco's Modified Eagle's Medium (DMEM) (Gibco BRL, Gaithersburg, MD, USA) containing 10\% inactivated horse serum (Gibco BRL) and $10 \%$ fetal bovine serum (Gibco BRL) in a humidified atmosphere of $5 \% \mathrm{CO}_{2} / 95 \% \mathrm{O}_{2}$ at $37^{\circ} \mathrm{C}$. The culture medium was changed three times per week. Cells were removed from the flasks for subculture and for plating into assay dishes, using a $\mathrm{Ca}^{2+} / \mathrm{Mg}^{2+}$-free solution containing $172 \mathrm{mM} \mathrm{NaCl}, 5.4 \mathrm{mM} \mathrm{KCl}, 1 \mathrm{mM} \mathrm{NaH} \mathrm{PO}_{4}$ and $5 \cdot 6 \mathrm{mM}$ glucose at $\mathrm{pH} 7 \cdot 4$. After about $2 \mathrm{~min}$ in this solution, the cells were detached by tapping the side of the flask. The cells $\left(1 \times 10^{6}\right)$ were plated onto $35 \mathrm{~mm}$ polystyrene dishes and cultured with $2 \mathrm{ml}$ DMEM for 2 days as described above. Cells were then used for experiments in a serum-starved condition (Takekoshi et al. 2000).

\section{Tyrosine hydroxylase enzyme activity}

Tyrosine hydroxylase enzyme activity was measured by a method previously reported by Kumai et al. (1998). Experiments were initiated by replacing the cell culture medium with HEPES-buffered Krebs solution containing various concentrations of test substance and then incubating the cells for $10 \mathrm{~min}$ at $37^{\circ} \mathrm{C}$. Cells were homogenized in $0 \cdot 25 \mathrm{M}$ sucrose (50 volumes) with a glass tissue grinder. The standard incubation medium consisted of the following components in a total volume of $250 \mu \mathrm{l}$ : $100 \mu \mathrm{l}$ tissue homogenate, $40 \mu \mathrm{l}$ of $1 \mathrm{M}$ sodium acetate buffer $(\mathrm{pH} 6 \cdot 0), 40 \mu \mathrm{l}$ of $1 \mathrm{mM}$ L-tyrosine or D-tyrosine, $20 \mu \mathrm{l}$ of $1 \mathrm{M}$ 6-methyl-5,6,7,8-tetra-hydropterine in $1 \mathrm{M}$ 2-mercaptoethanol, $20 \mu \mathrm{l}$ of $20 \mathrm{mM}$ catalase and $30 \mu \mathrm{l}$ water. The medium was incubated at $37^{\circ} \mathrm{C}$ for $30 \mathrm{~min}$ and then the reaction was stopped with $1 \mathrm{M}$ perchloric acid, containing dihydroxy benzylamine as an internal standard, and $0.2 \mathrm{M}$ EDTA in an ice bath. Then, $1 \mathrm{M}$ potassium carbonate and $0.2 \mathrm{M}$ Tris $-\mathrm{HCl}(\mathrm{pH} 8 \cdot 5)$ containing $1 \%$ EDTA were added. The 3-(3,4-didihydroxyphenyl)-alanine (DOPA) was extracted by the aluminum oxide method. Forty microliters of extracted medium were mixed with $0 \cdot 1 \mathrm{~N} \mathrm{NaOH}$ and TSK-GEL ODS-120T (TOSOH, Japan) and analyzed by HPLC. The mobile phase consisted of the following components: $50 \mathrm{mM}$ sodium acetate, $20 \mathrm{mM}$ citric acid, $12.5 \mathrm{mM}$ sodium octyl sulfate, $1 \mathrm{mM}$ di-n-butylamine and $0 \cdot 134 \mathrm{mM}$ EDTA. All separations were performed isocratically at a flow rate of $0.6 \mathrm{ml} / \mathrm{min}$ at $28{ }^{\circ} \mathrm{C}$. The detector potential was maintained at $+0.65 \mathrm{~V}$. The $\mathrm{TH}$ enzyme activity was calculated as the amount of DOPA formed from tyrosine per milligram protein per minute.

\section{Real-time PCR analysis for TH $m R N A$ level}

TH mRNA level was determined by real-time PCR analysis, as described previously by Kitaoka et al. (2003). The PCR reaction mixture was prepared with a Taqman PCR master reagent kit (PE Applied Biosystems, Foster City, CA), according to the manufacturer's instructions. The thermal cycling protocol was $2 \mathrm{~min}$ at $50{ }^{\circ} \mathrm{C}$ and $10 \mathrm{~min}$ at $95^{\circ} \mathrm{C}$, and this was followed by 40 cycles of $95{ }^{\circ} \mathrm{C}$ for $15 \mathrm{~s}$ and $60{ }^{\circ} \mathrm{C}$ for $1 \mathrm{~min}$. Thermal cycling, fluorescence detection and data analysis were performed on the ABI PRISM 7700 Sequence Detector with the software provided with the instrument.

The sequences of synthetic oligonucleotide primers and probes were as follows: 
- TH, forward primer: AGA GGG ATG GGA ATG CTG TTC

- reverse primer: CGA GAC AAG GAG GAG GGT TTT

- TaqMan probe: AAC CTG CTC TTC TCC CTG A. For GAPDH detection, we used TaqMan GAPDH Detection Reagents (PE Applied Biosystems).

\section{PKC activity}

PKC activity was measured in cultured confluent cells as previously described (Takekoshi et al. 2001). Cell cultures (in $90 \mathrm{~mm}$ dishes) were incubated in control medium $(5 \%$ glucose) or with PrRP31 or PrRP20 for $10 \mathrm{~min}$. The cells were then harvested, homogenized by sonification in $20 \mathrm{mM}$ Tris- $\mathrm{HCl}(\mathrm{pH} 7 \cdot 5)$, and incubated for $30 \mathrm{~min}$ with $100 \mu \mathrm{l}$ reaction buffer solution containing a pseudosubstrate and various phospholipids from a commercially available kit (Pep Taq-nonradioactive PKC activity kit; Promega). The reaction was terminated by heating and the reaction mixture was separated into phosphorylated and nonphosphorylated substrates on a $0.9 \%$ agarose gel. For quantification, the gel bands were visualized by UV light and then excised, and the absorbance was measured at $570 \mathrm{~nm}$. The results were expressed in OD units

\section{Western blot analysis for ERKs, JNK and p38 MAPK activity}

Phosphorylation of ERKs, JNK and p38 MAPK proteins from porcine adrenal medullary cells was measured with an antibody kit (New England Biolabs, Beverly, MA, USA), according to the manufacturer's instructions (Ishii et al. 2001). Cells were starved for $4 \mathrm{~h}$ and then the medium was replaced with HEPES-buffered Krebs buffer including various test substances. Lysates were immunoprecipitated with anti-ERKs or anti-JNK antibody. Immunoprecipitates were subjected to $7 \cdot 5 \%$ SDS-PAGE and analyzed by immunoblotting with antiphosphotyrosine antibody. We also determined the total amount of ERK $\sqcup J N K$ and P38 by using antibodies specific to all forms of ERK, JNK and P38 respectively (pan-ERK). MAPK activity is represented as the relative ratio of the density of phospho-MAPKs to that of total (pan-) ERKs.

\section{Statistical analysis}

All data are expressed as means \pm S.E.M. The significance of differences in the data was determined by analysis of variance (ANOVA), and $P$ values less than 0.05 were considered significant. The number of replicates indicates the number of separate experiments.

\section{Results}

\section{Effect of either PrRP31 or PrRP20 on TH enzyme activity}

As shown in Fig. 1, PrRP31 at a concentration of $10 \mathrm{nM}$, $100 \mathrm{nM}$ or $1 \mu \mathrm{M}$ significantly increased $\mathrm{TH}$ enzyme activity by $2 \cdot 0-, 3 \cdot 1-$ and $4 \cdot 1$-fold over the basal value respectively $(P<0 \cdot 05)$. PrRP20 $(100 \mathrm{nM}$ and $1 \mu \mathrm{M})$ also significantly increased TH enzyme activity $1.6-$ and 1.9 fold over the basal value respectively $(P<0 \cdot 05)$. The stimulation in TH enzyme activity mediated by PrRP20 was significantly less than that for PrRP31. The PKC inhibitor, Ro-32-0432 (100 nM), significantly inhibited PrRP31-induced TH enzyme activity $(P<0 \cdot 05)$. Previously, we have demonstrated that the cAMP-PKA system is involved in PrRP31-induced catecholamine release (Nanmoku et al. 2003). Thus, we examined the effect of H89 (at $10 \mu \mathrm{M}$ ), a PKA inhibitor, on PrRP31induced catecholamine biosynthesis. H89 significantly inhibited PrRP31-induced TH enzyme activity $(P<0 \cdot 05)$. Neither H89 nor Ro 32-0432 affected the basal TH enzyme activity (data not shown).

Nicotine is known to stimulate catecholamine synthesis in chromaffin cells. Nicotine $(10 \mu \mathrm{M})$, which stimulated TH enzyme activity $2 \cdot 9$-fold over the basal value, was used as a convenient positive control in this study. Interestingly, the level of PrRP31 (100 nM)-induced TH enzyme activity was similar to that observed for nicotine.

\section{Effect of either PrRP31 or PrRP20 on TH mRNA expression}

As shown in Fig. 2, PrRP31 at a concentration of $10 \mathrm{nM}$, $100 \mathrm{nM}$ or $1 \mu \mathrm{M}$ significantly increased TH mRNA level by $2 \cdot 3-, 3 \cdot 6-$ and $4 \cdot 0-$ fold over the basal value respectively $(P<0 \cdot 05)$. PrRP20 at $10 \mathrm{nM}, 100 \mathrm{nM}$ or $1 \mu \mathrm{M}$ also increased the TH mRNA level by $1 \cdot 8-, 2 \cdot 2-$ and $3 \cdot 1$-fold over the basal value respectively $(P<0 \cdot 05)$. However, the PrRP20-stimulated TH-mRNA level was significantly reduced compared with that for PrRP31. Both Ro-320432 and H89 inhibited the PrRP31-induced TH mRNA level. Neither H89 nor Ro 32-0432 affected the basal TH mRNA level (data not shown). In PC12 cells, it has been shown that PKC is upstream of Raf, which in turn results in the activation of ERKs (Sozeri et al. 1992, Kolch et al. 1993). Thus, we examined whether ERKs are involved in PrRP31-induced TH mRNA level. Pretreatment of cells with the MEK-1-inhibitor PD-98059 $(50 \mu \mathrm{M})$ significantly reduced the PrRP31 (100 nM)-induced TH mRNA level.

\section{Effect of either PrRP31 or PrRP20 on PKC activity}

As shown in Fig. 3, PrRP31 at a concentration of $1 \mathrm{nM}$, $10 \mathrm{nM}, 100 \mathrm{nM}$ or $1 \mu \mathrm{M}$ significantly increased PKC activity by 1.4-, 1.7-, 1.9- and 2.3-fold over the basal value respectively $(P<0 \cdot 05)$. PrRP20 at a concentration of $10 \mathrm{nM}, 100 \mathrm{nM}$ or $1 \mu \mathrm{M}$ also caused an increase in PKC activity by $1 \cdot 4-, 1 \cdot 6-$ and $1 \cdot 7$-fold over the basal value respectively $(P<0 \cdot 05)$. However, the PrRP20-stimulated PKC activity was significantly less than that of PrRP31. 


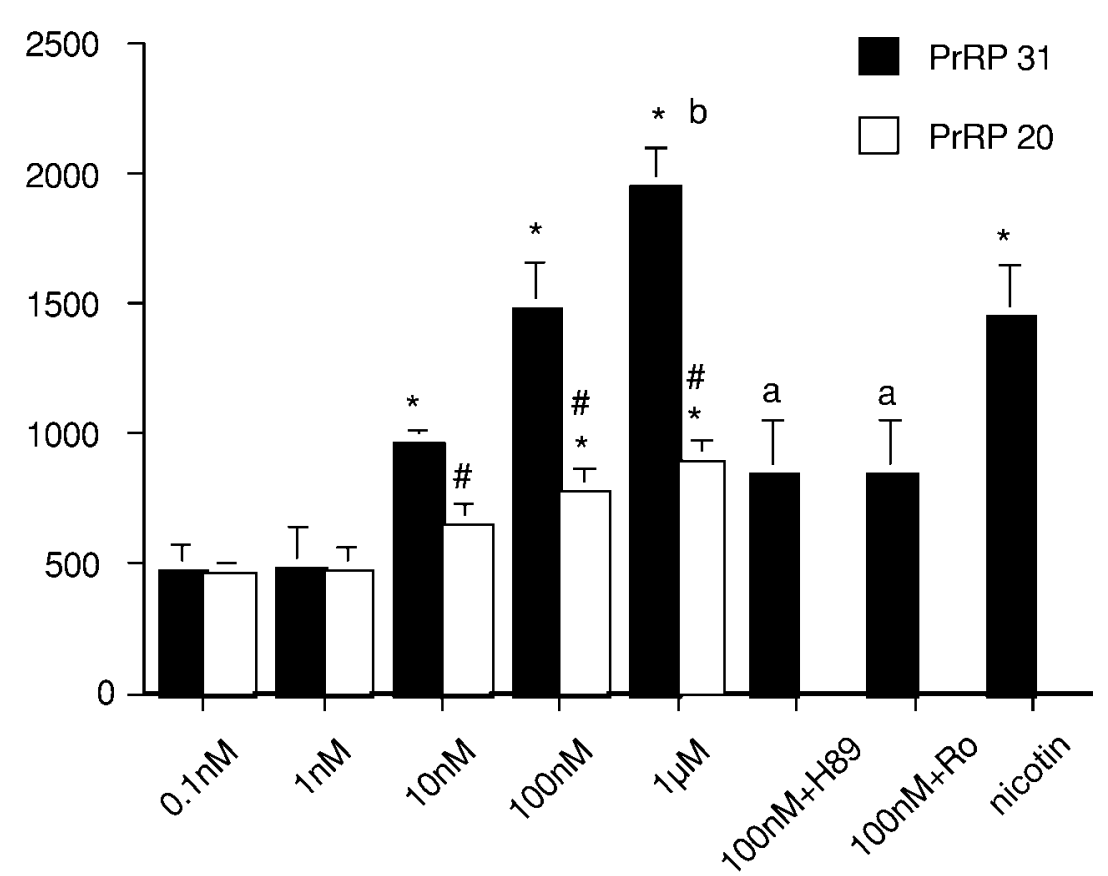

Figure 1 Effect of PrRPs on TH enzyme activity in PC12 cells. Cells were treated with various concentrations $(0 \cdot 1 \mathrm{nM}$ to $1 \mu \mathrm{M})$ of rat PrRP20 or PrRP31. Other cells were preincubated with either H89 $(10 \mu \mathrm{M})$ or Ro-32-0432 $(100 \mathrm{nM})$ for $30 \mathrm{~min}$ and then exposed to rat PrRP31 (at $100 \mathrm{nM}$ ) for 5 min. In addition, some cells were treated with nicotine $(10 \mu \mathrm{M})$ in the absence of PrRP. TH enzyme activity was then measured as described in Materials and Methods. The data shown are mean values \pm S.E. $(n=2)$ (experiments were carried out twice in triplicate). ${ }^{*}$ Significantly different $(P<0 \cdot 05)$ from the basal value; \#significantly different $(P<0 \cdot 05)$ from the value induced by PrRP31; ${ }^{a}$ significantly different $(P<0.05)$ from the value induced by PrRP31 $(100 \mathrm{nM})$ alone;

${ }^{\mathrm{b}}$ significantly different $(P<0 \cdot 05)$ from the value induced by nicotine $(10 \mu \mathrm{M})$ alone.

\section{Effect of PrRP31 on ERKs, JNK and p38 MAPK activity}

As shown in Fig. 4, PrRP31 $(1 \mu \mathrm{M})$ significantly induced increases in ERKs (p44+p42) and JNK (p54+p46) activity by about $2 \cdot 1$ - and $2 \cdot 9$-fold respectively. In contrast, PrRP31 did not affect P38 MAPK activity.

\section{Discussion}

The results presented in this study show that both PrRP31 and PrRP20 stimulate increased levels of TH enzyme activity and TH mRNA in parallel, suggesting that both mechanisms contribute to PrRP-induced catecholamine biosynthesis (Figs 1 and 2).

We have also demonstrated that both PrRP31 and PrRP20 significantly increase PKC activity in PC12 cells (Fig. 3). Interestingly, the increase in TH enzyme activity and mRNA level evoked by both PrRP31 and PrRP20 was inhibited by $100 \mathrm{nM}$ Ro-32-0432 (Figs 1 and 2). This would suggest that the stimulatory effect of PrRP on TH enzyme activity and mRNA level in chromaffin cells is mediated, at least in part, by the PKC pathway.
It is well established that PKC exerts stimulatory effects on both TH enzyme activity and TH mRNA (Holz et al. 1982, Plevin \& Boarder 1988). Thus, it is likely that both PrRP31 and PrRP20 stimulate PLC breakdown via its receptor, leading to stimulation of the PKC pathway. This, in turn, results in the stimulation of TH enzyme activity and $\mathrm{TH}$ synthesis.

The PKA inhibitor H89 (at $10 \mu \mathrm{M}$ ) attenuated PrRP31-induced TH synthesis (Figs 1 and 2), indicating that the PKA pathway might be involved. These findings agree with our previous report that both PrRP31 and PrRP20 stimulate an increase in the level of cAMP (Takekoshi et al. 2003). Taken together, these results suggest that the effects of PrRP are mediated through both the PKA and PKC pathways. This conclusion is supported by the finding that either a PKA inhibitor or a PKC inhibitor moderately, but significantly, inhibit PrRP31induced TH enzyme activity and TH mRNA accumulation (Fig. 2). Interestingly, the results described here are reminiscent of those for the strong secretogogue pituitary adenylate cyclase-activating polypeptide (PACAP), which is known to be coupled with both the PKA and PKC 


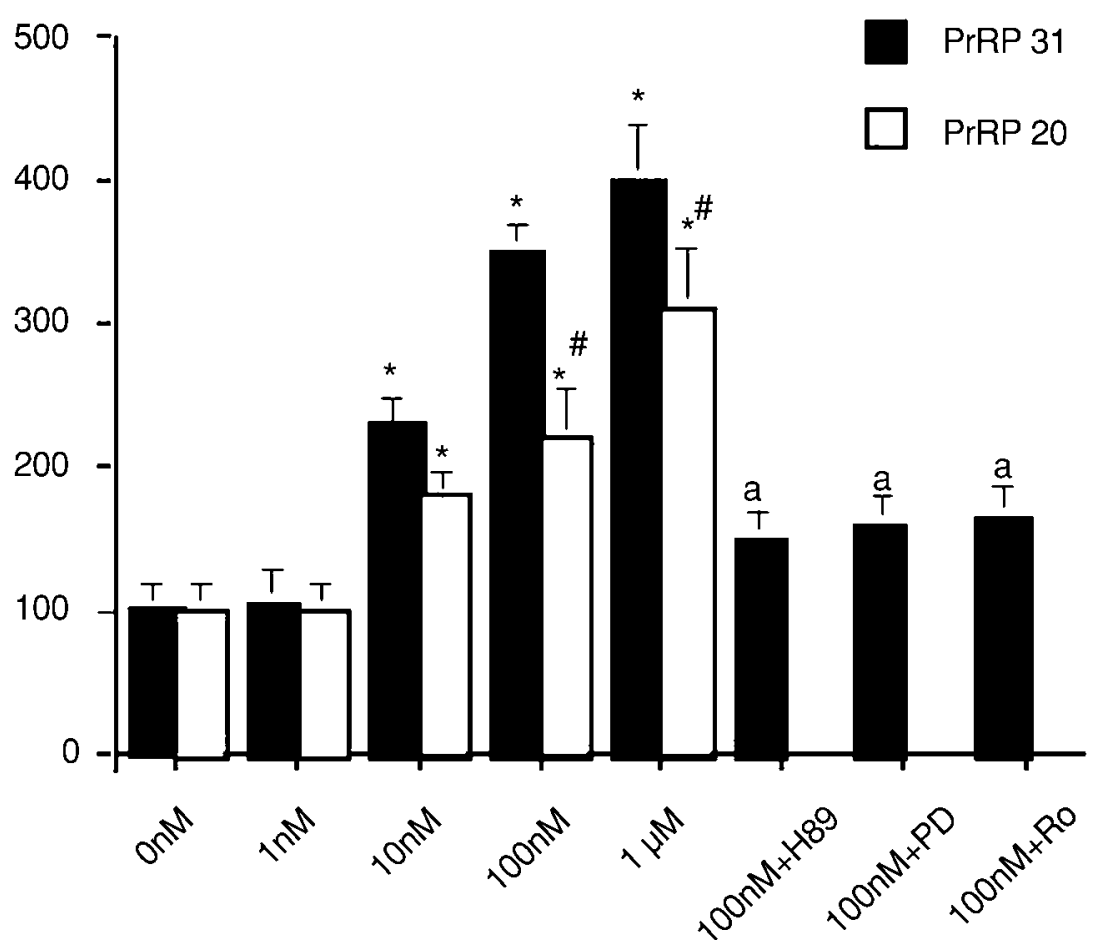

Figure 2 Effect of PrRPs on TH mRNA level in PC12 cells. Cells were treated with various concentrations $(0 \cdot 1 \mathrm{nM}$ to $1 \mu \mathrm{M})$ of rat PrRP20 or PrRP31 for $8 \mathrm{~h}$. Other cells were preincubated for either 30 min with H89 $(10 \mu \mathrm{M})$ or Ro-32-0432 (100 nM), or 60 min with PD98059 $(50 \mu \mathrm{M})$, and then exposed to rat PrRP31 (100 nM) for $8 \mathrm{~h}$. CDNA from PC12 cells was characterized by a real-time PCR method, as described in Materials and Methods. The data shown are mean values \pm S.E. $(n=2)$ (experiments were carried out twice in triplicate). *Significantly different $(P<0 \cdot 05)$ from the basal value; \#significantly different $(P<0.05)$ from the value induced by PrRP31; ${ }^{a}$ significantly different $(P<0.05)$ from the value induced by PrRP31 (100 nM) alone. TH mRNA levels are normalized to GAPDH levels in the same sample.

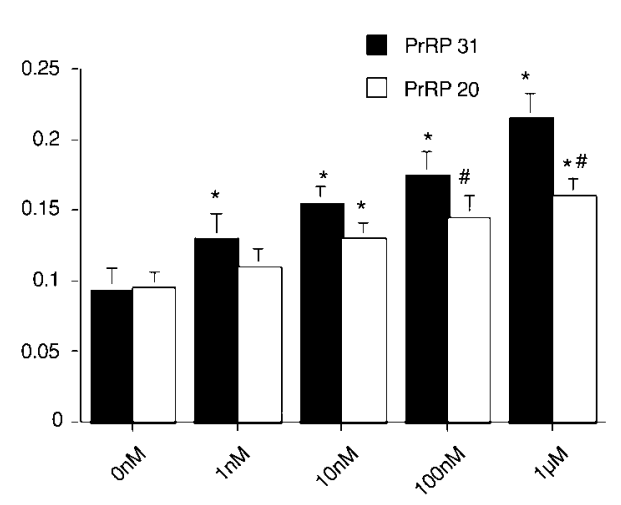

Figure 3 Effect of PrRP on PKC activity in PC12 cells. Cells were incubated with various concentrations $(1 \mathrm{nM}$ to $1 \mu \mathrm{M})$ of rat PrRP20 or PrRP31 for 10 min. PKC activity was then measured as described in Materials and Methods. The values represent the means \pm S.E. $(n=2)$ (experiments were carried out twice in triplicate). *Significantly different $(P<0 \cdot 05)$ from the basal value; \#significantly different $(P<0 \cdot 05)$ from the value induced by PrRP31. pathways. Indeed, using porcine adrenal medullary cells (Isobe et al.1996), we have previously shown that PACAP stimulates an increase in the level of TH mRNA in both a PKA- and PKC-dependent manner.

We also tested the effect of PrRP31 on a number of key kinase enzymes involved in signal transduction pathways. In our experimental system, PrRP31 stimulated ERK (2.1-fold) and JNK (2.9-fold), but not p38. The underlying mechanism to account for the different results obtained for the three MAPK families remains unclear. Kimura et al. (2000) reported that $1 \mu \mathrm{M}$ of PrRP31 markedly induced both JNK and ERK activity in rat pituitary GH3 cells. They propose that PrRP activates ERK and JNK, and that both cascades are necessary to elicit prolactin promoter activity. However, they did not examine the effect of PrRP31 on p38 MAP kinase activity.

Mounting evidence suggests that PKC is capable of phosphorylating and activating $\mathrm{Raf}$, which in turn results in the activation of ERKs in PC12 cells. PrRP31 appears to activate JNK in PC12 cells (Sozeri et al. 1992, Kolch et al. 1993) in a similar fashion to the activation of 

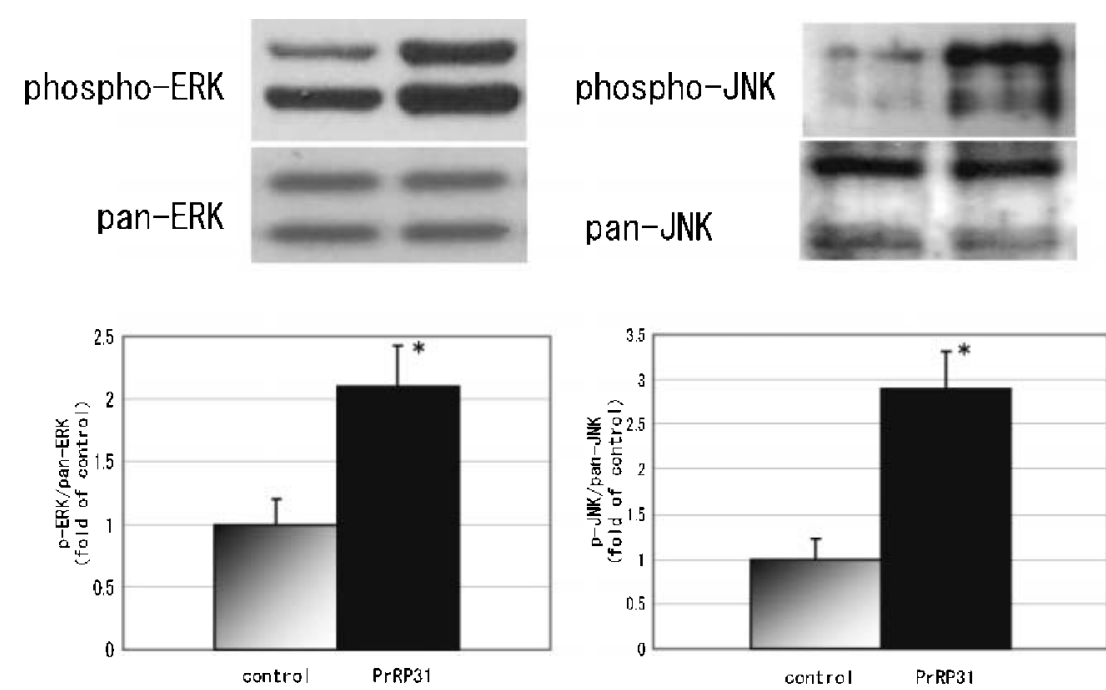

phospho-p38

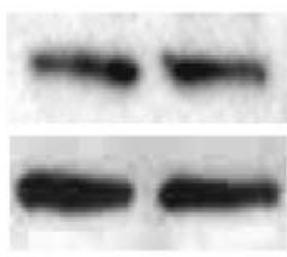

pan-p38
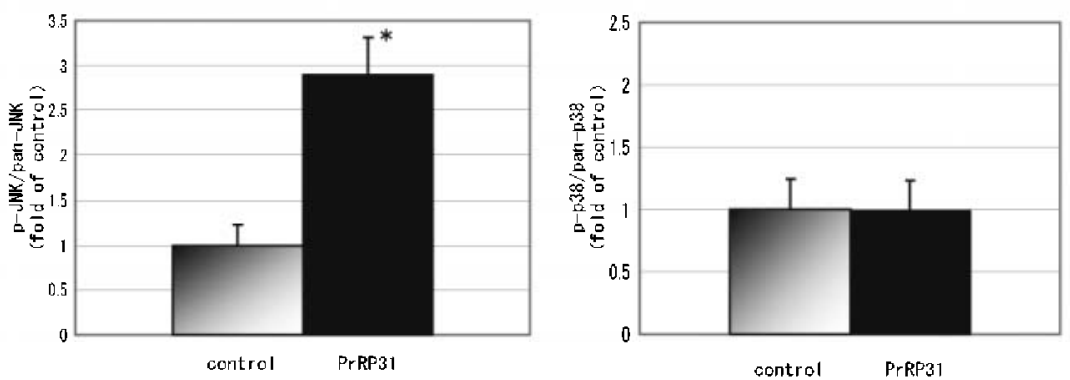

Figure 4 Effect of PrRP31 on ERKs, JNK and p38 MAPK activity. Cells were incubated for 10 min with PrRP31 (1 $\mu$ M). ERKs, JNK and p38 MAPK activity was then determined as described in Materials and Methods. Upper panel shows representative data. Lower panel shows summarized data of densitometrical analyses of ERKs activation. MAPK activity is represented as the relative ratio of the density of phosphoMAPKs against that of total (pan-) ERKs. Relative ratio in control was expressed as 1 arbitrary unit. $n=2$; experiments were carried out twice in duplicate. ${ }^{*} P<0 \cdot 05$.

ERKs. Indeed, c-fos protein can be phosphorylated at Ser 374 by ERK (Chen et al. 1993). In addition, other kinases, including Fos-regulating kinase (FRK), PKA and ribosomal S-6 kinase, have been shown to phosphorylate c-fos protein (Deng \& Karin 1994, Taylor et al. 1993). JNK phosphorylates c-jun at Ser 63 and Ser 73 (Hibi et al. 1993). Transcriptional activation of TRE (tetradecanoyl phorbol 13-acetate (TPA)-responsive elements), containing promoters of genes such as $\mathrm{TH}$, is mediated by the AP-1 complex, composed of different Fos/Jun families (Le Bourdelles et al. 1988, Gizang-Ginsberg \& Ziff 1994, Whitmarsh \& Davis 2000). Thus, the activation of ERKs induced by PrRP appears to be important in regulating $\mathrm{TH}$ transcription through AP-1 formation. Our observation that the PrRP31-induced increase in TH-mRNA is significantly inhibited by PD-98059 supports this proposal.

Although the physiologic role of the peptide other than its prolactin-releasing properties remains unclear (Matsumoto et al. 1999), Samson et al. (2000) have shown that intracerebroventricular administration of both PrRP31 and PrRP 20 significantly increases the blood pressure in a conscious rat. Apart from this 'central effect' of PrRP, we have shown that PrRP directly stimulates both catecholamine synthesis and secretion in the adrenal medulla. Thus, it is tempting to speculate that the "peripheral actions' of PrRP on the adrenal medulla could be responsible, at least in part, for the stimulatory effect of PrRP on blood pressure under physiologic conditions. Further studies, involving the in vivo administration of PrRP, will be needed to clarify to what extent the 'peripheral actions' of PrRP contribute to regulating blood pressure via catecholamine secretion from the adrenal medulla.

\section{Acknowledgement}

This work was supported in part by a grant from the Ministry of Education, Sports and Culture of Japan (no. 15590967) to K T. The authors declare that there is no conflict of interest that would prejudice the impartiality of this scientific work.

\section{References}

Alessi DR, Cuenda A, Cohen P, Dudley DT \& Saltiel AR 1995 PD 098059 is a specific inhibitor of the activation of mitogen-activated protein kinase kinase in vitro and in vivo. Journal of Biological Chemistry $27027489-27494$.

Chabot-Fletcher M \& Breton JJ 1998 Effect of staurosporine on transcription factor NF-B in human keratinocytes. Biochemical Pharmacolgy 56 71-78.

Chen C, Dun SL, Dun NJ \& Chang JK 1999 Prolactin-releasing peptide-immunoreactivity in A1 and A2 noradrenergic neurons of the rat medulla. Brain Research 822 276-279.

Chen RH, Abate C \& Blenis J 1993 Phosphorylation of the c-Fos transrepression domain by mitogen-activated protein kinase and 90-kDa ribosomal S6 kinase. PNAS 90 10952-10956.

Deng T \& Karin M 1994 c-Fos transcriptional activity stimulated by H-Ras-activated protein kinase distinct from JNK and ERK. Nature 371 171-175.

Dunn LA \& Holz RW 1983 Catecholamine secretion from digitonin-treated adrenal medullary chromaffin cells. Journal of Biological Chemistry 258 4989-4993.

Fujii R, Fukusumi S, Hosoya M, Kawamata Y, Habata Y, Hinuma S, Sekiguchi M, Kitada C, Kurokawa T, Nishimura O et al. 1999 Tissue distribution of prolactin-releasing peptide (PrRP) and its receptor. Regulatory Peptides 83 1-10.

Fujiwara K, Matsumoto H, Yada T \& Inoue K 2005 Identification of the prolactin-releasing peptide-producing cell in the rat adrenal gland. Regulatory Peptides 126 97-102. 
Gizang-Ginsberg E \& Ziff EB 1994 Fos family members successively occupy the tyrosine hydroxylase gene AP-1 site after nerve growth factor or epidermal growth factor stimulation and can repress transcription. Molecular Endocrinology 8 249-262.

Hibi M, Lin A, Smeal T, Minden A \& Karin MI 1993 Identification of an oncoprotein- and UV-responsive protein kinase that binds and potentiates the c-Jun activation domain. Genes and Development 7 $2135-2148$

Hinuma S, Habata Y, Fujii R, Kawamata Y, Hosoya M, Fukusumi S, Kitada C, Masuo Y, Asano T, Matsumoto H et al. 1998 A prolactin-releasing peptide in the brain. Nature 393 272-276.

Holz RW, Senter RA \& Frye RA 1982 Relationship between $\mathrm{Ca}^{2+}$ uptake and catecholamine secretion in primary dissociated cultures of adrenal medulla. Journal of Neurochemistry 39 635-646.

Hwang O, Park SY \& Kim KS 1997 Protein kinase A coordinately regulates both basal expression and cyclic AMP-mediated induction of three catecholamine-synthesizing enzyme genes. Journal of Neurochemistry 68 2241-2247.

Iijima N, Kataoka Y, Kakihara K, Bamba H, Tamada Y, Hayashi S, Matsuda T, Tanaka M, Honjyo H, Hosoya M et al. 1999 Cytochemical study of prolactin-releasing peptide (PrRP) in the rat brain. Neuroreport 10 1713-1716.

Ishii K, Takekoshi K, Shibuya S, Kawakami Y, Isobe K \& Nakai T 2001 Angiotensin subtype-2 receptor (AT2) negatively regulates subtype-1 receptor (AT1) in signal transduction pathways in cultured porcine adrenal medullary chromaffin cells. Journal of Hypertension 19 1991-1999.

Isobe K, Yukimasa N, Nakai T \& Takuwa Y 1996 Pituitary adenylate cyclase-activating polypeptide induces gene expression of the catecholamine synthesizing enzymes, tyrosine hydroxylase and dopamine beta hydroxylase, through $3^{\prime}, 5^{\prime}$-cyclic adenosine monophosphate- and protein kinase C-dependent mechanisms in cultured porcine adrenal medullary chromaffin cells. Neuropeptides 30 167-175.

Kimura A, Ohmichi M, Tasaka K, Kanda Y, Ikegami H, Hayakawa J, Hisamoto K, Morishige K, Hinuma S, Kurachi H \& Murata Y 2000 Prolactin-releasing peptide activation of the prolactin promoter is differentially mediated by extracellular signal-regulated protein kinase and c-Jun $\mathrm{N}$-terminal protein kinase. Journal of Biological Chemistry 275 3667-3674.

Kitaoka Y, Kumai T, Isenoumi K, Kitaoka Y, Motoki M, Kobayashi S \& Ueno S 2003 Neuroprotective effect of nitric oxide against NMDA-induced neurotoxicity in the rat retina is associated with tyrosine hydroxylase expression. Brain Research 977 46-54.

Kolch W, Heidecker G, Kochs G, Hummel R, Vahidi H, Mischak H, Finkenzeller G, Marme D \& Rapp UR 1993 Protein kinase C alpha activates RAF-1 by direct phosphorylation. Nature 364 249-252.

Kumai T, Tanaka M, Tateishi T, Watanabe M, Nakura H, Asoh M \& Kobayashi S 1998 Effects of anti-androgen treatment on the catecholamine synthetic pathway in the adrenal medulla of spontaneously hypertensive rats. Naunyn-Schmiedeberg's Archives of Pharmacology 357 620-624.

Langmead CJ, Szekeres PG, Chambers JK, Ratcliffe SJ, Jones DN, Hirst WD, Price GW \& Herdon HJ 2000 Characterization of the binding of $[(125) \mathrm{I}]$-human prolactin releasing peptide (PrRP) to GPR10, a novel G protein coupled receptor. British Journal of Pharmacology 131 683-688.

Le Bourdelles B, Boularand S, Boni C, Horellou P, Dumas S, Grima B \& Mallet J 1988 Analysis of the $5^{\prime}$ region of the human tyrosine hydroxylase gene: combinatorial patterns of exon splicing generate multiple regulated tyrosine hydroxylase isoforms. Journal of Neurochemistry 50 988-991.

Libert F, Vassart G \& Parmentier M 1991 Current developments in G-protein-coupled receptors. Current Opinion in Cell Biology 3 218-223

Marchese A, Heiber M, Nguyen T, Heng HH, Saldivia VR, Cheng R, Murphy PM, Tsui LC, Shi X, Gregor P et al. 1995 Cloning and chromosomal mapping of three novel genes, GPR9, GPR10, and GPR14, encoding receptors related to interleukin 8 , neuropeptide Y, and somatostatin receptors Genomics 29 335-344.

Marley PD, Thomson KA \& Bralow RA 1995 Protein kinase A and nicotinic activation of bovine adrenal tyrosine hydroxylase. British Journal of Pharmacology 114 1687-1693.

Maruyama M, Matsumoto H, Fujiwara K, Kitada C, Hinuma S, Onda H, Fujino M \& Inoue K 1999 Immunocytochemical localization of prolactin-releasing peptide in the rat brain. Endocrinology 140 2326-2333.

Matsumoto H, Murakami Y, Horikoshi Y, Noguchi J, Habata Y, Kitada C, Hinuma S, Onda H \& Fujino M 1999 Distribution and characterization of immunoreactive prolactin-releasing peptide (PrRP) in rat tissue and plasma. Biochemical and Biophysical Research Communications 257 264-268.

Nanmoku T, Takekoshi K, Isobe K, Kawakami Y, Nakai T \& Okuda Y 2003 Prolactin-releasing peptide stimulates catecholamine release but not proliferation in rat pheochromocytoma PC12 cells. Neuroscience Letters 350 33-36.

Nieminen ML, Brandt A, Pietilä P \& Panula P 2000 Expression of mammalian RF-amide peptides neuropeptide FF (NPFF), prolactin-releasing peptide (PrRP) and the PrRP receptor in the peripheral tissues of the rat. Peptides 21 1695-1701.

Plevin R \& Boarder MR 1988 Stimulation of formation of inositol phosphates in primary cultures of bovine adrenal chromaffin cells by angiotensin II, histamine, bradykinin, and carbachol. Journal of Neurochemistry 51 634-641.

Roland BL, Sutton SW, Wilson SJ, Luo L, Pyati J, Huvar R, Erlander MG \& Lovenberg TW 1999 Anatomical distribution of prolactin-releasing peptide and its receptor suggests additional functions in the central nervous system and periphery. Endocrinology 140 5736-5745.

Samson WK, Resch ZT \& Murphy TC 2000 A novel action of the newly described prolactin-releasing peptides: cardiovascular regulation. Brain Research 858 19-25.

Sozeri O, Vollmer K, Liyanage M, Frith D, Kour G, Mark GE 3d \& Stabel S 1992 Activation of the c-Raf protein kinase by protein kinase C phosphorylation. Oncogene 7 2259-2262.

Stoehr SJ, Smolen JE, Holz RW \& Agranoff BW 1986 Inositol trisphosphate mobilizes intracellular calcium in permeabilized adrenal chromaffin cells. Journal of Neurochemistry 46 637-640.

Takahashi K, Totsune K, Murakami O, Sone M, Noshiro T, Hayashi Y, Sasano H \& Shibahara S 2002 Expression of prolactin-releasing peptide and its receptor in the human adrenal glands and tumor tissues of adrenocortical tumors, pheochromocytomas and neuroblastomas. Peptides 23 1135-1140.

Takekoshi K, Ishii K, Kawakami Y, Isobe K \& Nakai T 2000 kappa-opioid inhibits catecholamine biosynthesis in PC12 rat pheochromocytoma cell. FEBS Letters 477 273-277.

Takekoshi K, Ishii K, Kawakami Y, Isobe K \& Nakai T 2001 Leptin stimulates catecholamine synthesis in a PKC-dependent manner in cultured porcine adrenal medullary chromaffin cells. Endocrinology 142 4861-4871.

Taylor LK, Landreth GE \& Marshak DR 1993 Identification of a nerve growth factor- and epidermal growth factor-regulated protein kinase that phosphorylates the protooncogene product c-Fos. PNAS 90 368-372.

Welch SK, O'Hara BF, Kilduff TS \& Heller HC 1995 Sequence and tissue distribution of a candidate $\mathrm{G}$-coupled receptor cloned from rat hypothalamus. Biochemical And Biophysical Research Communications 209 606-613.

Whitmarsh AJ \& Davis RJ 2000 A central control for cell growth. Nature 403 255-256.

Received 14 March 2005

Accepted 15 April 2005 